\title{
Non-acceptance of permanent methods of contraception-a threat to small family norm: a cross-sectional study from the Northern state of India
}

\author{
Rajesh Kumar Singh, Amandeep Kaur*
}

Department of Community Medicine, Government Medical College, Haldwani, Nainital, Uttarakhand, India

Received: 07 August 2018

Accepted: 01 September 2018

\section{*Correspondence:}

Dr. Amandeep Kaur,

E-mail: dramankaur182@yahoo.com

Copyright: (C) the author(s), publisher and licensee Medip Academy. This is an open-access article distributed under the terms of the Creative Commons Attribution Non-Commercial License, which permits unrestricted non-commercial use, distribution, and reproduction in any medium, provided the original work is properly cited.

\begin{abstract}
Background: India is second most populous country of the world after China and is expected to surpass China by 2024. In order to balance the population growth, replacement-level fertility - total fertility rate of 2.1 - needs to be achieved and sustained even at sub-national level. Acceptance of permanent family planning methods by young couples can be an effective way of eliminating risk of future pregnancies. The objective of the present study was to assess acceptance and determinants of acceptance of permanent methods of contraception among couples with two or more living children.

Methods: A community based cross-sectional study was conducted during September 2017-April 2018 in Haldwani block of Nainital District of Uttarakhand, India. The study participants were selected by multi-stage sampling and were interviewed using semi-structured and pretested questionnaire. The statistical analysis was done using the software R. Chi-square test was used to test association between variables.

Results: Among 221 interviewed study subjects, only $34.39 \%$ were using permanent method of contraception and out of these, $96.05 \%$ were acceptors of tubectomy while only $3.95 \%$ preferred vasectomy. One in four couples were not using any contraceptive method and rest chose temporary contraceptive techniques. Non-acceptors were especially high in case of couples with women belonging to lower age-group, living in joint families, having only one or no male child and with formal schooling.

Conclusions: Non-acceptance of permanent method of contraception for limiting the family after two children was very high in the community and desire for male child being its important determinant.
\end{abstract}

Keywords: Determinants, Family Planning, Fertility Rate, Tubectomy, Vasectomy

\section{INTRODUCTION}

According to the Indian census 2011, the population of India was exactly $1,210,193,422$, which means India has crossed the 1-billion mark. ${ }^{1}$ This is the second most populous country of the world after China. As per United Nations projections, by 2024 , the population of India is expected to surpass China. ${ }^{2}$

Uncontrolled population growth possesses the substantial threat to India's health, political, economic and social development. In view of that Family Planning Programme was launched in India way back in 1952 with the objective of reducing birth rate to the extent necessary to stabilise the population. ${ }^{3}$ The programme consumed massive resources and attention by policy makers but still has not been able to address the huge population growth. In spite of the various policies and efforts, Census 2011 showed a decadal population growth rate of $17.64 .^{4}$

To balance the population growth, each generation should exactly replace itself, which means achieving 
replacement-level fertility - total fertility rate (TFR) of 2.1-sustained over a sufficiently long period; this also means two children per woman. ${ }^{5}$ The Two-Child Norm policy was first recommended by the National Development Council's Committee on Population in 1992 in order to move India towards its goal of replacement level fertility by 2010; which has been introduced and revoked in many states of India over time. 6

According to Sample Registration Survey, the TFR in India still was 2.3 in $2016 .^{7}$ So the National Health Policy 2017 has again set the target to reduce total fertility rate (TFR) to 2.1 at sub-national and national level by $2025 .^{8}$ In view of that "two-child" norm becomes imperative.

Indian states of Kerala and Tamil Nadu achieved TFR of 2.1 with the start of the millennium with substantially lower expenditure per eligible couple due to high acceptance rate of sterilization a contraceptive method. ${ }^{9}$

Therefore, acceptance of permanent family planning methods by young couples with two living children is most safe and cost-effective way of eliminating the risk of future pregnancies thus sustaining to two child policy and preventing further population growth. In fact, in India the scope of permanent methods of family planning has been broadened to include families with one child. ${ }^{10}$ However, National family Health Survey (NFHS)-4 statistics have shown reduction in male and female sterilization by $0.7 \%$ and $1.3 \%$ respectively. ${ }^{11}$

Surprisingly a similar trend was noted in Uttarakhand state with reduction rate of $1.1 \%$ for vasectomy and $5.2 \%$ for tubectomy. ${ }^{12}$ Non-acceptance of the permanent method of contraception by couples with two living children is a threat to two child norm and achievement of TFR of 2.1 .

There is a paucity of studies regarding acceptance of permanent methods of family planning among the most eligible and priority group, i.e., couples with more than two living children. Therefore, the present study was conducted in Haldwani Block of Nainital district of Uttarakhand to assess the acceptance of permanent methods of family planning and determine sociodemographic factors associated with non-acceptance among families where women are in reproductive age group of 20-49 years with two or more living children.

\section{METHODS}

Study design: A community based cross sectional study conducted during September 2017-April 2018.

Study settings: Study was conducted in the Haldwani block of Nainital district of Kumaon Division of Uttarakhand state of India. Haldwani has the maximum population among the eight subdivisions of the Nainital district. Government Medical College and Hospital,
Haldwani is the only government tertiary care centre in the Kumaon Division of Uttarakhand. Department of Community Medicine provides community outreach services in Haldwani through its three centres - one rural health training centre situated in the rural area and two centres under urban health training centre situated in urban areas of Haldwani.

\section{Sample size}

Assuming prevalence (p) of acceptance of permanent methods of contraception among married couples with two living children to be $50 \%$ and taking absolute allowable error (d) as 7\%, the sample size was calculated using the formula $\left(Z_{1}-\alpha\right)^{2} \mathrm{p}(1-\mathrm{p}) / \mathrm{d}^{2}$ at $95 \%$ confidence interval.

As it is a community-based study, $10 \%$ non-response rate was added and final sample size of 216 was obtained. It was finally decided to include sample of 80 from three different selected study areas.

\section{Sampling technique}

A multi-stage sampling technique was used for the selection of study sample (Figure 1).

- $\quad$ One community development block (Haldwani) was selected purposively from the total eight blocks in Nainital district of Uttarakhand.

- One village or urban area was selected randomly from the villages/urban areas adopted by each of the three centres under the department of Community Medicine.

- From each selected village or urban area consecutive sampling procedure was adopted for identification of eligible participants till the required sample was achieved.

\section{Inclusion criteria}

- Women in the age group of 20 to 49 years having two or more living children and who gave consent were included.

\section{Exclusion criteria}

- Women who were pregnant or who had undergone hysterectomy or the ones not willing to participate were excluded from the study.

A survey was conducted in the selected areas with semistructured and pretested questionnaire to collect the information about socio-demographic characteristics and family planning practices.

\section{Statistical analysis}

Data was entered in MS excel and descriptive analysis was done using numbers and percentages. The statistical 
analysis was done using the software R ( R Foundation for Statistical Computing, Vienna, Austria; http://www.Rproject.org) version 3.4.2 (2017-09-28). ${ }^{13}$ Chi-square test was used test association between variables and $\mathrm{P}$ - value $<0.05$ was considered as statistically significant.Ethical consideration: Due ethical clearance was taken from the Institute Ethical Committee of Government Medical College Haldwani, Nainital, India.

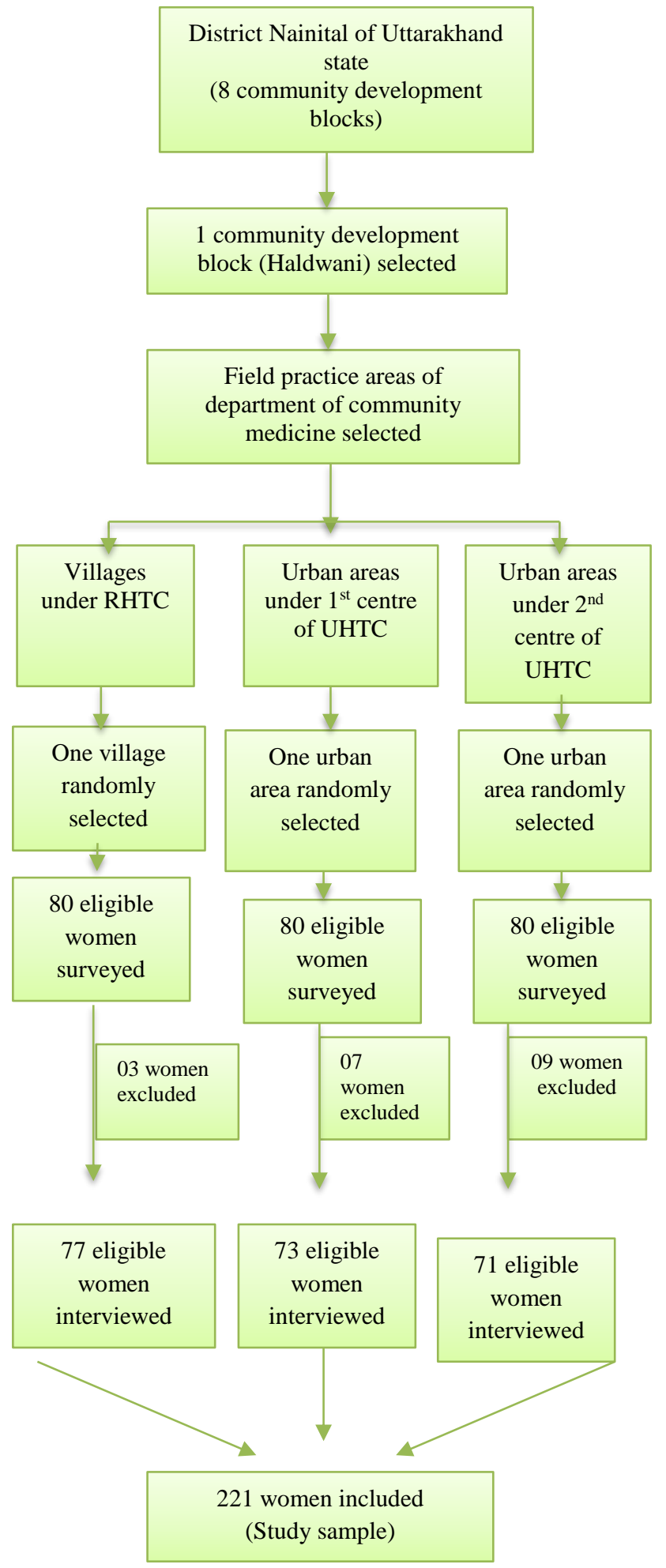

Figure 1: Selection of study sample

\section{RESULTS}

A total of 221 subjects participated in the present study. The mean (SD) age of women in the study was 31.21 (05.26) years and the median age was 30 years ranging from 20-43 years. About half (52.90\%) of women were in age-group of 30-39 years. Fifteen percent of study subjects were illiterate.

Majority (78.73\%) were residing in nuclear families. Around forty percent of couples had more than two living children. The detailed socio-demographic profile of the interviewed subjects is given in Table 1 .

Table 1: Socio-demographic profile of study participants.

\begin{tabular}{|c|c|c|c|}
\hline Variables & & Frequency & Percent \\
\hline \multirow{3}{*}{ Age of wife } & $20-29$ & 82 & 37.10 \\
\hline & $30-39$ & 117 & 52.90 \\
\hline & $40-49$ & 22 & 10.00 \\
\hline \multirow{5}{*}{$\begin{array}{l}\text { Education status } \\
\text { of wife }\end{array}$} & Illiterate & 34 & 15.38 \\
\hline & Primary & 33 & 14.93 \\
\hline & Secondary & 82 & 37.10 \\
\hline & $\begin{array}{l}\text { Higher } \\
\text { secondary }\end{array}$ & 32 & 14.48 \\
\hline & $\begin{array}{l}\text { Graduate } \\
\text { and above }\end{array}$ & 40 & 18.10 \\
\hline \multirow{5}{*}{$\begin{array}{l}\text { Education status } \\
\text { of husband }\end{array}$} & Illiterate & 27 & 12.22 \\
\hline & Primary & 28 & 12.67 \\
\hline & Secondary & 71 & 32.13 \\
\hline & $\begin{array}{l}\text { Higher } \\
\text { secondary }\end{array}$ & 45 & 20.36 \\
\hline & $\begin{array}{l}\text { Graduate } \\
\text { and above }\end{array}$ & 50 & 22.62 \\
\hline \multirow{3}{*}{ Religion } & Hindu & 198 & 89.59 \\
\hline & Muslim & 19 & 08.60 \\
\hline & Sikh & 4 & 01.81 \\
\hline \multirow{2}{*}{ Residence } & Rural & 77 & 34.84 \\
\hline & Urban & 144 & 65.16 \\
\hline \multirow{2}{*}{ Type of family } & Joint & 47 & 21.27 \\
\hline & Nuclear & 174 & 78.73 \\
\hline \multirow{5}{*}{$\begin{array}{l}\text { No. of living } \\
\text { children }\end{array}$} & 2 & 131 & 59.28 \\
\hline & 3 & 60 & 27.15 \\
\hline & 4 & 23 & 10.41 \\
\hline & 5 & 5 & 02.26 \\
\hline & 6 & 2 & 00.90 \\
\hline
\end{tabular}

The present study showed that permanent method of contraception was used by only $34.39 \%$ of all the interviewed couples, out of which majority $(96.05 \%)$ were acceptors of tubectomy while only $3.95 \%$ preferred vasectomy. Eighty-six (38.91\%) couples with more than two living children were using temporary method of contraception, of which majority were either using condoms or oral contraceptive pills (OCPs). Interestingly, only $4.94 \%$ of the target couples chose long term temporary contraceptive - Copper-T. One in four couples were not using any contraceptive method (Table 2). 
Table 2: Contraceptive practices among families with two living children.

\begin{tabular}{|llll|}
\hline Current contraception practices $(\mathbf{n = 2 2 1})$ & Frequency & Percent & $95 \%$ CI \\
\hline No modern method of family planning & 59 & 26.70 & $21.09-33.13$ \\
\hline Temporary methods of family planning & 86 & 38.91 & $32.51-45.70$ \\
\hline Permanent methods of family planning & 76 & 34.39 & $28.23-41.10$ \\
\hline Type of contraceptive method $(\mathrm{n}=162)$ & & & \\
\hline Tubectomy & 73 & 45.06 & $37.30-53.05$ \\
\hline Vasectomy & 03 & 01.85 & $00.47-05.74$ \\
\hline Copper-T & 08 & 04.94 & $02.31-09.83$ \\
\hline Oral contraceptive pills & 39 & 24.07 & $17.86-31.54$ \\
\hline Condom & 39 & 24.07 & $17.86-31.54$ \\
\hline CI confidence interval & & & \\
\hline
\end{tabular}

Table 3: Association of socio-demographic variables and acceptance of permanent methods of family planning.

\begin{tabular}{|c|c|c|c|c|c|c|}
\hline \multirow{3}{*}{\multicolumn{2}{|c|}{ Socio-demographic variables }} & \multicolumn{4}{|c|}{ Permanent method of contraception } & \multirow{3}{*}{ p-value } \\
\hline & & \multicolumn{2}{|c|}{ Acceptors $(n=76)$} & \multicolumn{2}{|c|}{ Non-acceptors $(n=145)$} & \\
\hline & & Number & $\%$ & Number & $\%$ & \\
\hline \multirow{3}{*}{ Age of wife } & $20-29$ & 16 & 19.50 & 66 & 80.50 & \multirow{3}{*}{0.001} \\
\hline & $30-39$ & 49 & 41.90 & 68 & 58.10 & \\
\hline & $40-49$ & 11 & 50.00 & 11 & 50.00 & \\
\hline \multirow{2}{*}{ Literacy status of wife } & Illiterate & 14 & 41.18 & 20 & 58.82 & \multirow{2}{*}{0.478} \\
\hline & Literate & 62 & 33.16 & 125 & 66.84 & \\
\hline \multirow{2}{*}{ Literacy status of husband } & Illiterate & 14 & 51.85 & 13 & 48.15 & \multirow{2}{*}{0.068} \\
\hline & Literate & 62 & 31.96 & 132 & 68.04 & \\
\hline \multirow{2}{*}{ Residence } & Rural & 21 & 27.27 & 56 & 72.73 & \multirow{2}{*}{0.138} \\
\hline & Urban & 55 & 38.19 & 89 & 61.81 & \\
\hline \multirow{2}{*}{ Type of family } & Joint & 8 & 17.02 & 39 & 82.98 & \multirow{2}{*}{0.008} \\
\hline & Nuclear & 68 & 39.08 & 106 & 60.92 & \\
\hline \multirow{2}{*}{ Religion } & Hindu & 69 & 34.85 & 129 & 65.15 & \multirow{2}{*}{0.849} \\
\hline & Others & 7 & 30.43 & 16 & 69.57 & \\
\hline \multirow{3}{*}{ No. of children } & 02 & 32 & 24.43 & 99 & 75.57 & \multirow{3}{*}{0.0003} \\
\hline & 03 & 32 & 53.33 & 28 & 46.67 & \\
\hline & $\geq 4$ & 12 & 40.00 & 18 & 60.00 & \\
\hline \multirow{3}{*}{ No. of male children } & $\overline{0}$ & 2 & 6.25 & 30 & 93.75 & \multirow{3}{*}{0.001} \\
\hline & 1 & 38 & 36.54 & 66 & 63.46 & \\
\hline & 2 or more & 36 & 42.35 & 49 & 57.65 & \\
\hline
\end{tabular}

In the current study, acceptance of permanent methods for limiting family size was significantly less in couples with women belonging to lower reproductive age-group, and acceptance increased with the age of the woman. Literacy status of the wife or husband was not seen to play any significant role in acceptance of permanent methods of contraception. Significantly higher acceptance was observed in couples with nuclear families and with more number of children, especially, male children (Table 3).

\section{DISCUSSION}

India's rapidly growing population is the most serious obstacle to its economic development. With the acceptance of the small-family norm, though the existing size of population will not reduce abruptly, but it will positively slow-down the rate at which population is increasing.

In the present study, only one-third of the couples were found to be using permanent methods of contraception. Tubectomy was accepted by $73(33.03 \%)$ and vasectomy by only three $(1.36 \%)$ couples. In India, the data of National Family Health Survey (NFHS)-4, too shows high $(36.0 \%)$ and extremely low $(0.3 \%)$ preference for tubectomy and vasectomy, respectively. ${ }^{11}$ Similarly, NFHS-4 results for Uttarakhand depicts acceptors of female and male sterilization as $27.4 \%$ and $0.7 \%$, respectively. ${ }^{12}$ Studies done by Banerjee B and Gadre et al. also depict inclination towards tubectomy over vasectomy. ${ }^{14,15}$

In the present study, couples not using any contraceptive method-neither permanent nor temporary - in spite 
having at least two living children were $26.7 \%$. Only $4.94 \%$ couples opted for Copper-T while majority chose either condoms or OCPs. The percentage of intra-uterine contraceptive device (IUCD) usage in the present study is slightly higher than the results provided by NFHS-4 where use of IUCD has been depicted as $1.5 \%$ and $1.6 \%$ in India and Uttarakhand, respectively. ${ }^{11,12}$ Nonacceptance of long acting IUCDs may be associated with discomfort of undergoing a procedure and fear of sideeffects, which may further be linked with lack of awareness that the side-effects are minimum and subside within a few months. Interestingly, preference for long acting temporary methods of family planning is quite high in Ethiopia as shown in the study conducted by Mota et al.; but the methods preferred by Ethiopian women were mainly implants, and acceptance of Copper containing IUCDs has been revealed to be relatively low. ${ }^{16}$

Number of living children was found to significantly affect the decision of limiting family by undergoing sterilization operation. More than half of the couples with three children accepted permanent method while acceptance was only one-fourth in case of two children. Similar results were obtained by Girdhar et al. in a study conducted in rural Ludhiana; they too found parity to be significantly related to non-acceptance. ${ }^{17}$ Bharadwaj et al., depicted highest (more than 80\%) acceptance in couples with two children in their decadal analysis of trends of permanent sterilization. ${ }^{18}$ But their study was facility based, and the population visiting a health institute may have differential characteristics and may not represent the community; this may explain the difference with present study.

Non-acceptors of permanent methods were seen to be higher in couples with women belonging to lower agegroup and decreased with increase in age of women. Girdhar et al had similar findings, but Banerjee B. in West Bengal made different observations. ${ }^{14,17}$ In India there is trend of marriage of women in early twenties, so children of women belonging to age-group 20-29 years are usually of younger age-group; the surety of thriving of these children increases with increase in age which in turn lessens the possible need to conceive in future and thence increases the acceptance of permanent methods of contraception in women of higher age-group.

Although studies conducted by Banerjee B and Bharadwaj et al show that permanent contraceptive methods was opted more by educated females, but in present study, acceptance of permanent method was found to be higher among illiterate women and husbands, however the association was not significant. ${ }^{14,18}$ Even though it might seem ironical that acceptance of permanent method was significantly lower among literate couples, but it can be explained by the fact that literacy helps married men and women choose other methods among the basket of approaches for contraception as per their needs. Also, literate couples feel more in control of their sexual life and therefore do not feel the need of undergoing sterilization for limiting their family. Acceptors of permanent methods of contraception were more in urban area than in rural, although the difference was not significant, which may be due to better availability and accessibility of health facilities in urban areas.

Religion of the couples was not found to affect the decision of accepting permanent methods of contraception, but in other studies acceptance of contraception was found to be significantly less among the Muslims. ${ }^{14,18,19}$ Non-acceptors were significantly higher among the couples living in joint families. This suggests the influence of family in decision making among couples. Girdhar et al has shown acceptance of permanent methods more in subjects residing in nuclear family, but in the study by Banerjee B no difference was observed regarding contraceptive usage in relation to type of family. Discrepancies can be linked with diverse socio-demographic backgrounds of different parts of India. $^{14,17}$

Although acceptance of permanent methods of contraception increased with increase in number of male children, but around six percent couples opted for limiting their families even without a male child and one third couples if they had one male child. In a decadal analysis, Bharadwaj et al. have depicted $32.3 \%$ couples accepting sterilization operation without a male child and $44.3 \%$ after one male child; but their study was hospital based. Girdhar et al, too found that more than half of the couples with two male children accepted permanent method, while only $1.2 \%$ couples with no male children made that choice. ${ }^{17,18}$ This result points towards the fact that inclination of having male child is hindering the choice of limiting family after two children. Pathak et al., in their study, has also concluded male child preference as the major reason for not accepting contraception after two children. ${ }^{20}$

\section{CONCLUSION}

From the present study it can be concluded that nonacceptance of permanent method of contraception for limiting the family after two children was very high in the community. Even inclination towards long acting contraceptive methods like, IUCDs was also seen to be very less. Non-acceptors were especially high in case of women belonging to lower age-group, those living in joint families, and among educated couples. Desire for male child was found to significantly affect limiting the family size.

\section{Recommendations}

It is recommended to create awareness regarding permanent methods of contraception and emphasize that uneasiness linked with the procedure of sterilization is far less a price paid than the difficulties associated with an 
unplanned / unwanted pregnancy. For couples not willing to undergo sterilization other long acting contraceptives like IUCDs and injectables can also be publicized. Also, awareness regarding empowerment and importance of girl child in a society is the need of the hour if we want to make family planning and two child norm a success.

\section{ACKNOWLEDGMENTS}

We would like to acknowledge interns posted and the staff of urban and rural health and training centres, GMC, Haldwani-Mrs. Deepa Kholiya, Mr. G.S. Rawat, Mr. Vijay Verma, Mrs. Nema Chauhan, Miss Prita Priya, Miss Nawab Bano and Mr. R.K. Singh-for providing support in conduct of study.

Funding: No funding sources Conflict of interest: None declared

Ethical approval: The study was approved by the Institutional Ethics Committee

\section{REFERENCES}

1. CensusInfo India 2011 Final Population Totals - India Population size [Internet]. [cited 2018 May 7]. Available from: http://www.devinfo.org/indiacensuspopulationtotals201 1/libraries/aspx/Home.

2. United Nations, Department of Economic and Social Affairs, Population Division. World Population Prospects: The 2017 Revision, Key Findings and Advance Tables [Internet]. 2017 p. 5. Report No.: Working Paper No. ESA/P/WP/248. Available from: https://esa.un.org/unpd/wpp/publications/Files/WPP201 7_KeyFindings.pdf

3. India and Family Planning: An overview [Internet]. [cited 2018 May 7]. Available from: http://www.searo.who.int/entity/maternal_reproductive _health/documents/india-fp.pdf?ua=1

4. Annual Report of Department of Health and Family Welfare 2016-17 | Ministry of Health and Family Welfare | GOI [Internet]. [cited 2018 May 7]. Available from: https://mohfw.gov.in/annual-report-departmenthealth-and-family-welfare--2016-17

5. World Health Organization, Total Fertility Rate [Internet]. SEARO. Available from: http://www.searo.who.int/health_situation_trends/data/c hi/TFR/en/

6. Mason KO, Hartmann B. Reproductive Rights and Wrongs: The Global Politics of Population Control. Popul Dev Rev. 1995;21(4):885.

7. Total Fertility Rate (TFR) (Birth/ woman) | NITI Aayog, (National Institution for Transforming India), Government of India [Internet]. [cited 2018 Jun 1]. Available from: http://niti.gov.in/content/total-fertilityrate-tfr-birth-woman\#

8. National Health Policy 2017: Ministry of Health \& Family Welfare [Internet]. Available from: http://164.100.158.44/index1.php?lang=1\&level=1\&su blinkid $=6471 \&$ lid $=4270$
9. Family Welfare. Human and Social Development. 9th Five Year Plan (Vol-2). [Internet]. [cited 2018 May 17]. Available from: http://planningcommission.nic.in/plans/planrel/fiveyr/9t $\mathrm{h} / \mathrm{vol} 2 / \mathrm{v} 2 \mathrm{c} 3-5 . \mathrm{htm}$

10. Reference Manual for Female Sterilization. [Internet]. Family Planning Division. Ministry of Health \& Family Welfare. Government of India; 2014. Available from: https://www.ukhfws.org/uploads/documents/doc_3768_ ref-manual-for-female-sterilization.pdf

11. India Factsheet. National family health survey (NFHS4) 2015-16 [Internet]. Mumbai: International Institute for Population Sciences (IIPS); 2017. [cited 2018 May 7]. Available from: http://rchiips.org/NFHS/pdf/NFHS4/India.pdf

12. State Factsheet Uttarakhand. National family health survey (NFHS-4) 2015-16 [Internet]. Mumbai: International Institute for Population Sciences (IIPS); 2017. [cited 2018 May 7]. Available from: http://rchiips.org/NFHS/pdf/NFHS4/UT_FactSheet.pdf

13. R Core Team (2017). R: A language and environment for statistical computing. R Foundation for Statistical Computing, Vienna, Austria. [Internet]. [cited 2018 May 17]. Available from: https://www.r-project.org/

14. Banerjee B. Socioeconomic and cultural determinants on acceptance of permanent methods of contraception. J Fam Welf. 2004;50(1):7.

15. Gadre S, Gadre A. Preferences of eligible women from an Indian medical college hospital for adapting contraceptives. Int $\mathbf{J}$ Reprod Contracept Obstet Gynecol. 2016;5(1):35-40.

16. Mota K, Reddy S, Getachew B. Unmet need of longacting and permanent family planning methods among women in the reproductive age group in Shashemene town, Oromia region, Ethiopia: a cross sectional study. BMC Womens Health. 2015;15(1):51.

17. Girdhar S, Chaudhary A, Gill PJS, Soni RK, Sachar RK. Contraceptive Practices And Related Factors Among Married Women In A Rural Area Of Ludhiana. Internet J Health [Internet]. 2009 [cited 2018 May 8];12(1). Available from: http://ispub.com/IJH/12/1/5428\#

18. Bharadwaj MK, Patrikar S, Singh S. Determinant factors affecting the trends of permanent sterilization: a decadal analysis in a tertiary care institute. Int J Reprod Contracept Obstet Gynecol. 2017;6(12):5348-53.

19. Kumar A, Bhardwaj P, Srivastava JP, Gupta P. A study on family planning practices and methods among women of urban slums of Lucknow city. Indian J Community Health. 2011;23(2):75-7.

20. Pathak V, Chandra M, Bisani VR. Challenges in utilisation of small family norm. Int $\mathrm{J}$ Reprod Contracept Obstet Gynecol. 2017;6(1):276-9.

Cite this article as: Singh RK, Kaur A. Nonacceptance of permanent methods of contraception-a threat to small family norm: a cross-sectional study from Northern state of India. Int J Reprod Contracept Obstet Gynecol 2018;7:4150-5. 